\title{
Effect of Ultrasonic Agitation on the Microtensile Bond Strength for Cementing Ceramic Inlays
}

\author{
Seramik İnleylerin Simantasyonunda Ultrasonik Aktivasyonun Mikrogerilim Bağlantı \\ Dayanımlarına Etkisi
}

Ebru SÜMER EKIN ${ }^{\circledR}$, Yalçın DEĞER ${ }^{\circledR}$, Zeynep BAŞAĞAOĞLU DEMIREKIN $®$

\begin{abstract}
Objectives: This in-vitro study was performed to assess the effect of ultrasonic agitation on microtensile bond strength [ $\mu \mathrm{TBS}$ ] of composite resin cements or self adhesive resin cements used for cementing ceramic inlays.

Materials and Methods: In the study, standardized Class 1 cavities were prepared on 72 human premolar teeth and impression was taken using elastomeric impression material. IPS e-max Press inlay restorations were prepared according to manufacturer's instruction. HF acid [9.5\%] and silane coupling agent was applied to the cementation surfaces of ceramic inlays. Firstly, teeth were randomly divided into four groups for four different resin cements [RelyX ARC, Panavia F 2.0, RelyX U200 and G-Cem]. And then, each resin cement group was divided into two subgroups according to the cementation by finger pressure or ultrasonic agitation. While 64 teeth were used for microtensile bond strength test, 8 teeth [including one in each group] were used for scanning electron microscopy evaluation. At the end of the microtensile test, samples were examined using a stereomicroscope for analysis of fracture type.

Results: The microtensile bond strengths of conventional resin cements [RelyX ARC and Panavia F 2.0] were significantly higher than self adhesive resin cements' [RelyX U200 and G-Cem] bond strengths $[p<0.05]$. In each cements' subgroups, the two cementation techniques did not effect the microtensile bond strength of each cements $[\mathrm{p}>0,05]$. The effect of ultrasonic agitation on microtensile bond strength of resin cements was not statistically significant for all groups.
\end{abstract}

Zeynep Başağaoğlu Demirekin (四)

Suleyman Demirel University, Faculty of Dentistry, Department of

Prosthodontics, Isparta, Turkey.

e-mail: dtzeynepbasagaoglu@yahoo.com.tr

Ebru Sümer Ekin

Diyarbakir Oral and Dental Health Center, Diyarbakir, Turkey

Yalçın Değer

Department of Prosthodontics, Faculty of Dentistry, Suleyman Demirel University, Isparta, Turkey

The study was supported by a grant of the DÜAPK-Dicle University Research Project Council [DUBAP] - 12-DH-05.

Submitted / Gönderilme: 14.09 .2020

Accepted/Kabul: 01.06.2021
Conclusions: In the present study, the best bonding performances were achieved with the etch-and-rinse and self-etch systems. Ultrasonic agitation did not influence the microtensile bond strength of resin cements.

Keywords: Ceramic inlay, self-adhesive resin cement, ultrasonic agitation, microtensile bond strength.

Öz

Seramik İnleylerin Farklı Rezin Simanlarla Simantasyonunda Ultrasonik Yerleştirme Tekniğinin Dentine Mikrotensil Bağlanma Dayanımı Üzerine Olan Etkisinin İn Vitro Değerlendirilmesi

Amaç: Seramik inleylerin rezin siman ya da self-adeziv rezin simanlarla simantasyonunda ultrasonik yerleştirme tekniğinin mikrotensil bağlanma dayanımlarına etkisinin değerlendirilmesi amaçland1.

Materyal ve Method: $\mathrm{Bu}$ in vitro çalışmada, periodontal ve ortodontik tedavi amacıyla çekimi yapılan 72 adet çürüksüz ve restorasyonsuz sağlam insan premolar dişi kullanıldı. Her bir dişe Sınıf 1 inley kavitesi açıldı ve dişlerin elastomerik ölçü maddesi ile ölçüsü alındı. Laboratuvarda IPS e-max Press (Ivoclar Vivadent, Schaan, Liechtenstein) seramik inley restorasyonları üretici firmanın talimatlarına göre hazırlandı. Tüm seramik inleylerin iç yüzeylerine HF asit $(\% 9,5)$ ve silan bağlanma ajanı uyguland. Dişler önce rastgele dört gruba ayrıldı ve her bir gruptaki dişler ikisi self-adeziv özelliğe sahip olan dört farklı rezin siman (RelyX ARC, Panavia F 2.0, RelyX U200 ve G-Cem) ile simante edilmek üzere ayrıld1. Her bir siman grubu da simantasyonun parmak basıncı ile ya da ultrasonik yerleştirme tekniği ile simantasyonuna göre iki alt gruba ayrıldı. Simantasyon işlemi her bir simanın üretici firma talimatına göre gerçekleştirildi. Örnekler, oda sıcaklığında (23 \pm 2 oC) hazırlandı. Etüvde ( Heraeus, Heraeus Instruments, Hanau, Germany ) distile su içinde $37^{\circ} \mathrm{C}$ 'de 48 saat bekletildi. 64 adet diş mikrotensil testi için kullanılırken, geriye kalan 8 adet diş ise (her bir gruptan birer tane olmak üzere) taramalı elektron mikroskobu (SEM) değerlendirmesinde kullanılmıştır.

Bulgular : $\mathrm{Bu}$ in vitro çalışmanın sonucunda, her iki geleneksel rezin simanın bağlanma dayanımı değerleri self adeziv rezin simanların bağlanma dayanımı değerlerinden istatistiksel olarak yüksek bulunmuştur $(\mathrm{p}<0,05)$. Her bir siman grubunun parmak basıncı ve ultrasonik yerleştirme tekniği ile simante edilen alt grupları arasında istatistiksel olarak anlamlı bir fark bulunmamıştır $(\mathrm{p}>0,05)$. 
Sonuç: Ultrason uygulamasının farklı rezin simanların dentine mikrotensil bağlanma dayanımları üzerinde herhangi bir etkisinin olmadığı bulunmuştur.

Anahtar Kelimeler: Seramik inleyler, self-adeziv rezin siman, ultrasonik aktivasyon, mikrogerilme bağlanma dayanımı.

\section{Introduction}

In recent years, the growing interest in aesthetics, especially for the posterior teeth, aesthetic inlays, and onlays, has taken the place of amalgam and cast gold inlays. With a minimal tooth preparation requirement, ceramic inlay and Onlay restorations are the conservative and esthetic approaches for posterior teeth with moderate tissue loss (1-5).

Clinical success with ceramic inlays/onlays has been assisted by developing a reliable bond of resin cement to dental tissues (6). The adhesion of ceramic to the tooth structure with composite resin-based adhesive materials increases the fracture resistance of the tooth and the restoration, improves marginal adaptation, prevents microleakage, and increases the long-term success of the treatment $(7,8)$. Although bonding to enamel and ceramic can be considered reliable, dentin bonding is usually the weakest link in the luting process (9). Because of its high organic content, dentin is a less favorable substrate for bonding than enamel. Therefore, it is important to improve dentin adhesion when cementing ceramic restorations (10).

Currently, resin cement can be classified as total-etch, self-etch, and self-adhesive resin cement, according to dental tissues treatment or adhesion strategy $(11,12)$. Selfadhesive resin cement was designed with the intent to overcome some of the disadvantages of both conventional and composite resin cement (11). These materials were developed to simplify clinical procedures and overcome multistep systems' technique sensitivity $(13,14)$.

Ultrasonic devices are used in various clinical applications in dentistry (15). Scaling can be applied for using different types of ultrasonic devices, endodontic treatment (16), cavity preparation, irrigation, polishing (17), and most frequently $(16,18-22)$. Ultrasonic instruments can also be used in cases such as removal of the intraradicular post (23), amalgam core (24) or broken canal instruments from the root canal and removal of a crown $(19,25,26)$, cleaning of the instrument before sterilization and dentures (27). Currently, ultrasonic devices can also be used to cement laminate veneers and fiber posts (17).
In ultrasonic instrumentation, the cement's vibration forces fill the surface irregularities between the restoration and the tooth tissue (25). The ultrasonic agitation provides an advantage by affecting the composite resin's thixotropic property $(11,28)$. The fluid properties of resin materials containing a high filler can be developed with ultrasonic agitation (11, 13, 29-31).

Some application modes of adhesives and different luting procedures have been reported in the literature to have better bond strengths, for example, precuring the adhesive systems $(32,33)$, applying constant pressure to the restoration during the cementation (34-37), or ultrasonic agitation $(13,29,31)$. Therefore, it would be worthwhile to investigate if ultrasonic agitation may help achieve better infiltration of conventional resin cement or self-adhesive cement, and as a consequence, improve the bond strength.

This in-vitro study aimed to evaluate the effect of the ultrasonic agitation on micro tensile bond strength of four different resin cement used for cementing ceramic inlays, to define the types of failures to evaluate the morphological changes in the dentine-resin-ceramic interfaces using a scanning electron microscope.

\section{Materials and Methods}

In this study, 72 caries and restoration-free extracted human premolars were used; 64 were used for the micro tensile test, and eight were used for SEM analysis.

Standardized Class I box preparations were made with 6-degree conical diamond inlay burs [acurata a-Diamant diamond burs no: 172, 544 and 545, Acurata, Germany] with a high-speed handpiece [KaVo Compact Torque 636P, Lot No:11-1029461, KaVo Dental GmbH, Bismarckring, Germany] utilizing water spray. $2 \mathrm{~mm}$ occlusal, $4 \mathrm{~mm}$ mesiolingual and $3 \mathrm{~mm}$ buccolingual reductions [with rounded internal angles] were made. No bevels were utilized in the preparation.

Impressions were made of teeth preparations with polyvinyl siloxane impression material [Elite P\&P, Zhermack, Italy]. They poured in a vacuum mixed die material [Alpha Die Mf, Schültz-Dental GmbH, Rosbach, Germany] according to the manufacturer's instructions. IPS e-max Press [ LT A1 Ingot, Lot No: P8-5002, IvoclarVivadent AG, Schaan, Liechtenstein] inlays were pressed. All procedures were performed with IPS e-max Press materials and protocol. 
The inlays' adhesive surfaces were conditioned with 9,5\% hydrofluoric acid gel [Porcelain etchant, Lot No: 110.000.1470, Bisco, Inc, Schaumburg, USA] for 20 seconds, then thoroughly rinsed with water and air-dried. A silane coupling agent [Clearfil Ceramic Primer, Lot No:00019D, Kuraray, Osaka, Japan] was applied to the cementation surfaces and allowed to react for 60 seconds.

\section{Cementation Procedures}

The 72 prepared teeth were randomly assigned to 4 types of cement groups; Panavia F 2.0, RelyX ARC, G-Cem, and RelyX U200 groups. Each of the four groups was further divided into two luting procedure groups; finger pressure and ultrasonic agitation. Cementation procedures were performed according to each resin type of cement' manufacturers' instructions. The specimens were cleaned with an air-water syringe and dried with cotton buds; subsequently, the cement was applied.

For all groups, the same steps were followed; cement was applied to the ceramic inlay's adhesive surface. Ceramic inlay was carried and placed onto the tooth using a clamp. Then, it was directly pressed on the cavity using finger pressure by the same operator.

In the cementation procedure with the ultrasonic agitation, after the restoration was moved to the cavity with tweezers, the placement procedure was made with the ultrasonic device in the same way for all the groups. The tip [G22, Lot No: Z217020, NSK, Nakanishi Inc, Japan] of the ultrasonic handpiece was applied perpendicularly on the middle of the occlusal surface of the inlay and switched on according to the manufacturer's instructions and in waterfree mode. This procedure was repeated until no new resin cement emerged along the inlay margins.

Both two luting procedure groups; the excess cement was LED cured unit for 40 second periods at each side of the restorations. After the light polymerizing, the restorations were polished with polishing discs.

After the cementation procedures, the teeth were embedded into auto polymerizing acrylic resin [Akrileks, Gülsa Tıbbi Cihazlar ve Malz. San. Ve Tic. Ltd. Şti, İzmir, Türkiye] . Samples were then sectioned perpendicularly to the adhesive interface using a precision cutter [Microcut, Precision Cutter, Metcon, Kemet IL, USA] under continuous running water. Each tooth was vertically cut into 'I' shaped sections approximately $1.2 \times 1.2 \mathrm{~mm}$ wide. A total of 128 samples, 16 per batch, were subjected to tensile strength. The specimens were not trimmed.

\section{Micro tensile Bond Strength Test}

The specimens were fixed to the micro tensile testing apparatus [Micro Tensile Tester, Lot No: T-61010K/ T-61020K, BISCO, Inc., Schaumburg, IL, USA] with cyanoacrylate adhesive [Zapit, Lot No: C26A, Dental Ventures of America, Inc., Corona, Calif, USA]. The specimens were then subjected to tensile forces at a crosshead speed of $1 \mathrm{~mm} / \mathrm{min}$ until fracture. The load $[\mathrm{Kg}]$ at the time of fracture was recorded and converted to $\mathrm{MPa}$. Each fractured surface was measured with the digital caliper to calculate the microtensile bond strength exactly. The same operator performed all of the cavity preparations, cementation procedures, specimen preparations, and tests.

\section{Mode of Failure}

After the $\mu$ TBS test, both the dentin and ceramic sides of fractured beams were examined under a stereomicroscope [Olympus C5060-ADU, Olympus Co, Tokyo, Japan] 30× or $40 \times$ magnification to determine the mode of failure. Failure modes were classified into three different types;

Type 1: Adhesive failure [at the resin-dentin interface or the resin ceramic interface]

Type 2: Cohesive failure [in dentin, in resin, or ceramic]

Type 3: Adhesive and cohesive failure [mixed failure].

\section{Scanning Electron Microscope Analysis}

One tooth from each experimental group was processed for morphological evaluation of the adhesive interface by scanning electron microscopy. The specimens were polished with 240,300 , and 600 grit silicon carbide metallographic papers. The specimens were etched for 3-5 seconds with $10 \%$ phosphoric acid, subsequently stored in $5 \% \mathrm{NaOCl}$ solution for 5 minutes, and rinsed with water. The dried surfaces were fixed to SEM holders, sputtercoated with gold [Bal-tec SCD 050 Sputter Coater, Bal-tec $\mathrm{AG}$, Liechtenstein] and then, examined with an SEM [LEO 440, Leica-Zeiss, Cambridge, UK] at $\times 500, \times 1000$, and $\times$ 2000 magnification. 


\section{Statistical Analysis}

All the study data were evaluated using SPSS v.15.0 for Windows and Medcalc for Windows XP software. One Way Anova test, Student-Newman-Keuls multiple comparison tests, Independent Student's t-test were used for statistical evaluations. All the tests were applied at a $95 \%$ confidence interval. A value of $\mathrm{p}<0.05$ was accepted as statistically significant.

\section{Results}

Table 1: The mean values and standard deviations of the groups' microtensile bond strength cemented with four different resin types of cement and two different cementation techniques.

\begin{tabular}{|l|l|l|}
\hline \multirow{2}{*}{ Cement } & Technique \\
\cline { 2 - 3 } & Finger pressure & Ultrasonic agitation \\
\hline Panavia-F & $14,8975(6,32886)$ & $10,9319(4,60819)$ \\
\hline RelyX ARC & $10,6338(2,35930)$ & $10,3294(5,00723)$ \\
\hline G-Cem & $3,5156(1,92528)$ & $4,8731(2,18627)$ \\
\hline RelyX U200 & $5,1100(2,33273)$ & $6,8413(2,83653)$ \\
\hline
\end{tabular}

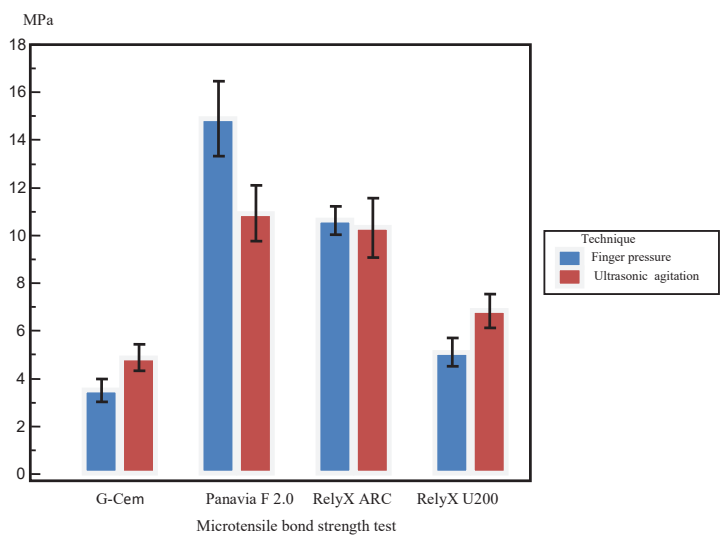

Graphic 1: The mean values of the microtensile bond strength of the groups

\section{All The Groups Where Cementation Was Applied With Finger Pressure}

The microtensile bond strength values of the RelyX ARC and Panavia F2.0 groups were determined to be statistically significantly higher than the bond strength test values of the self-adhesive resin cement groups [ $p<0.05]$. (Table 1) While no difference was observed between the self-adhesive resin cement groups [G-Cem and RelyX U200], the Panavia F 2.0 group's bond strength values were found to be statistically significantly higher than those of the RelyX ARC group.

\section{All The Groups Applied The Ultrasonic Agitation}

Table 2: A statistically significant difference was determined between all the groups that applied ultrasonic agitation, and these differences were statistically significantly different from each other $[\mathrm{p}<0.05]$.

\begin{tabular}{|l|l|l|}
\hline Group & Mean $(\mathrm{MPa})$ & $\begin{array}{l}\text { Statistical significance } \\
*(\mathrm{p}<0,05)\end{array}$ \\
\hline (1) G-Cem-U & 4,8731 & $(2)(3)$ \\
\hline (2) Panavia F 2.0-U & 10,9319 & $(1)(4)$ \\
\hline (3) RelyX ARC-U & 10,3294 & $(1)(4)$ \\
\hline (4) RelyX U200-U & 6,8413 & $(2)(3)$ \\
\hline
\end{tabular}

* Different numbers indicate significant differences $(\mathrm{p}<0,05)$.

The RelyX ARC and Panavia F2.0 groups' bond strength values were determined to be statistically significantly higher than the bond strength test values of the self-adhesive resin cement groups $[p<0.05]$. No statistically significant differences were determined between the bond strength values of the RelyX ARC and the Panavia F 2.0 groups nor between the self-adhesive resin cement groups.

Stereomicroscope analysis of fractured specimens revealed a prevalence of adhesive failures, especially at the resin-dentin interface for all groups, with few types of cement' differences. Most failures [92,18\%] were adhesive failure [Type 1] . Only one specimen [0,78\%] showed cohesive failure [ Type 2] was seen in Group PF. 9 specimens [7,03\%] showed mixed failure [Type 3] (Figure 1).
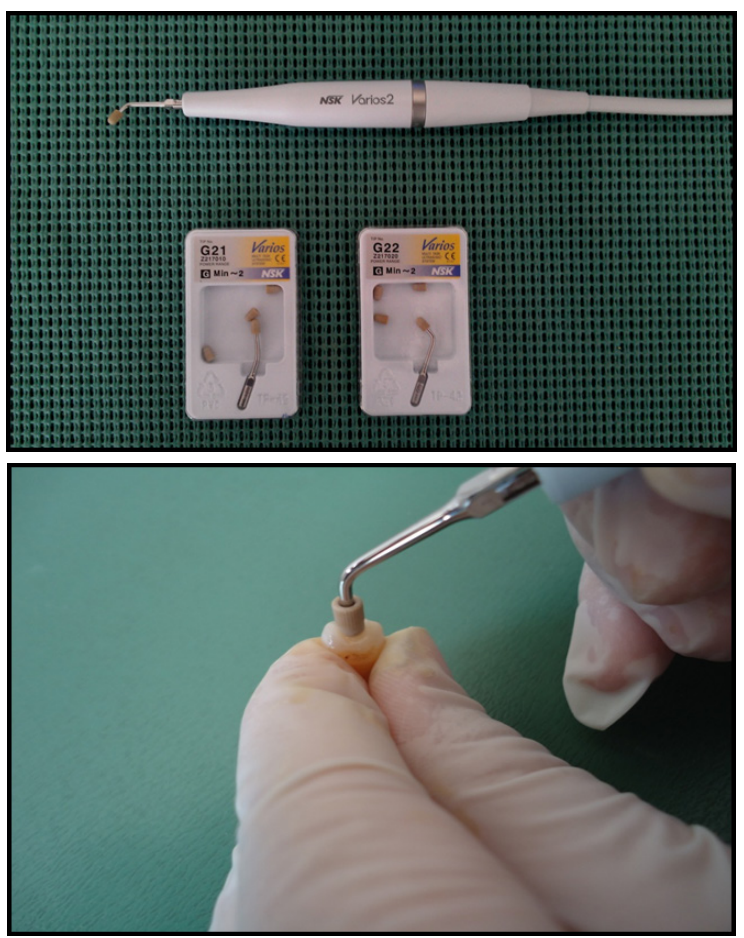

Figure 1: The ultrasonic device, application tips and cementation of ceramic inlay under ultrasonic agitation 
In the SEM evaluation of the self-adhesive resin cement groups, while a more superficial layer was formed in the cement's dentine surface, penetration of the resin into the dentinal tubules was seen in the Rely X ARC and Panavia F 2.0 groups. (Figure 2)

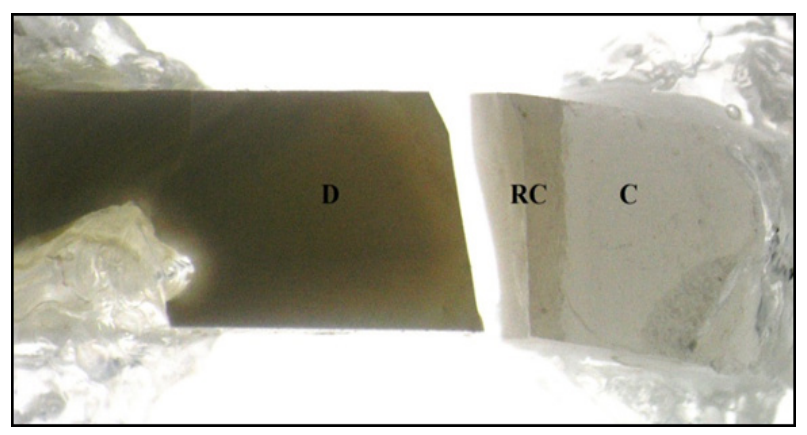

Figure 2: Stereomicroscope image of dentin-resin cement-ceramic interface of RelyX ARC- Finger pressure group. Adhesive failure between dentin and the resin cement is observed. (D: Dentin, R: Resin cement, C: Ceramic inlay)
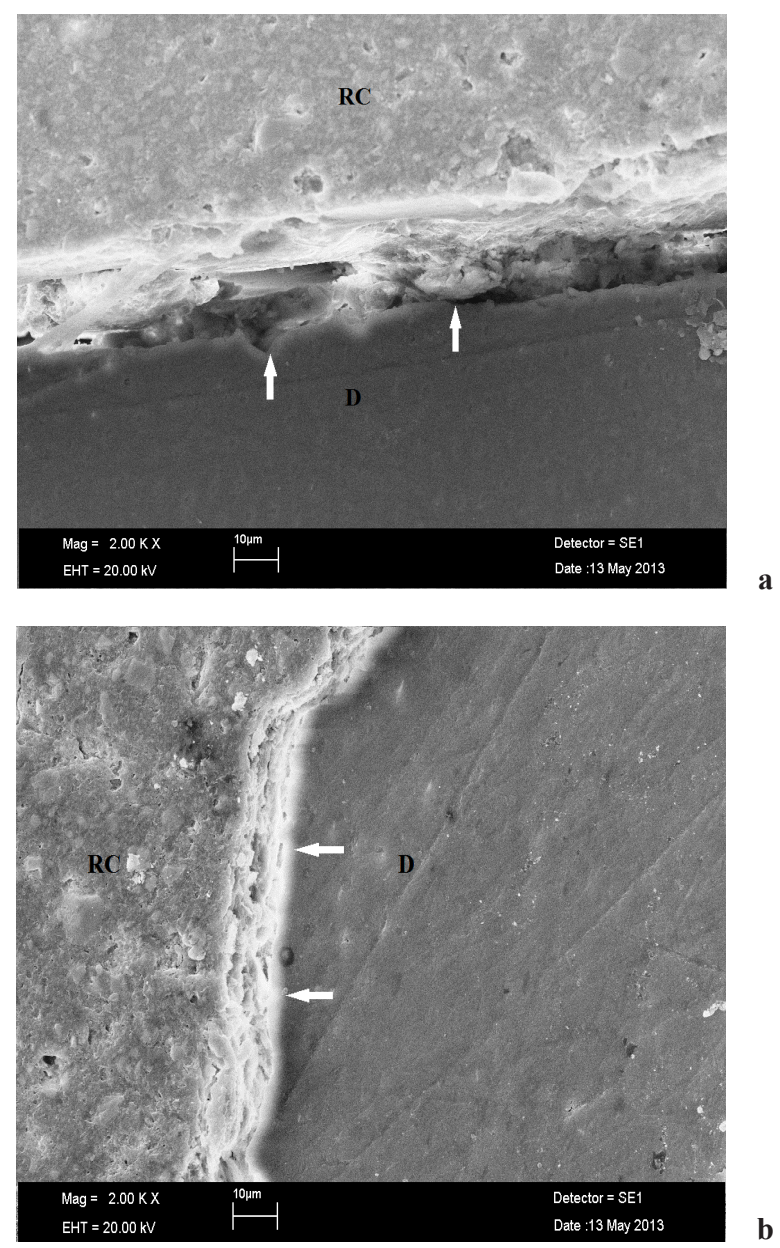

Figure 3: a) of cement-dentin interface of RelyX U200-Finger pressure group ( x 2000 magnification) and b) Ultrasonic agitation group ( x 2000 magnification).

\section{Discussion}

Ceramic inlays prepared with the Empress technique are used successfully in routine clinical practices (38). In many clinical studies, it has been reported that inlays and onlays prepared with pressable ceramic systems have a long clinical life (38-45).

The cementation stage is vital to the clinical success of full ceramic restorations (46). It is known that the factor providing the resistance of a ceramic restoration is the proper application of adhesive cementation (47).

In ceramic inlay cementation, dual-cured composite resin cement is generally preferred because of its excellent aesthetic and mechanical properties (48). The use of dualcured resin cement and dentine bonding agents reduces retention by providing airtight closure of the ceramic inlay in cementation. Also, ceramic restoration with composite resin cement forms a stress-breaking base in the interface $(49,50)$. In this study, 2-step etch-and-rinse, 1-step selfetch adhesive systems together with resin cement, and two different self-adhesive resin cement were used.

In previous studies, hydrofluoric acid and silane's application has been revealed to increase the bond strength of glass ceramics strengthened with lithium disilicate (5156). In the current study, after sanding off the IPS e-max press ceramics with $50 \mu \mathrm{m}$ aluminum oxide sand in all the groups, 9.5\% $\mathrm{HF}$ and a single bottle of silane coupling agent which contains 3-methacryloxyprophil-three methoxy silane, 10-methacryloyloxydecyl dihydrogen phosphate [MDP], and ethanol was used.

As total-etch systems include acute and multistep stages, events can occur, such as a change in the bonding efficacy, postoperative sensitivity, and indirect failure in the restoration (57). Therefore, self-etch systems, which are less invasive, have been developed $(50,58)$. In recent years, despite the tendency to produce simplified self-etch bonding systems, some studies have shown that self-etch systems' bonding efficacy is weaker than that of total-etch systems (59-62).

Self-adhesive resin cement used in this study [RelyX U200 and G-Cem] contains functional phosphoric acid monomers. These functional acidic monomers possibly contribute to the adhesion $(63,64)$. G-Cem self-adhesive resin cement contains UDMA as a cross-linking monomer due to a lower molecular weight and greater flexibility of the urethane linkage (65). GC's bonding mechanism is based on the glass ionomer technology modified by exchanging 
polyacrylic acid with the acidic functional monomers [4META] and phosphoric acid esters (66).

The self-etch approach of Panavia F 2.0 is based upon the dissolution of the smear layer, without the subsequent removal of the dissolved calcium phosphates, as there is no rinse phase (67). Functional monomers like 10-methacryloyloxydecyl dihydrogen phosphate have been proven to interact with this residual hydroxyapatite through primary ionic binding (68).

The adhesive mechanism of two-step etch-and-rinse systems [ like RelyX ARC used in this study] involves a phosphoric acid-etch step that within enamel produces etchpits in the hydroxyapatite-rich substrate and within dentin demineralizes up to a depth of a few micrometers to expose a hydroxyapatite-deprived collagen mesh. The next step of these systems involves applying and curing a composite primer-adhesive resin (67).

To date, researchers have mostly used shear and tensile bond strength tests. Classic shear and tensile bond strength tests are made on wide-tooth surface areas. As the surface area is wide $\left[7-12 \mathrm{~mm}^{2}\right]$, an accumulation of stress occurs, which is not homogenous, and therefore local stress areas are formed on the restoration surface. Consequently, failures in the samples are often seen in a cohesive type $(69,70)$. It is thought that reliable information has not been provided to evaluate this type of failure $(71,72)$. For the shear test, as failures are from one of the materials and not seen in the adhesive region, the results may not be true or can lead to misinterpretation, and criticisms can be made that stress distribution has not developed homogeneously in the adhesive interface $(71,73)$. The microtensile test method was developed to overcome this problem, which is more homogenous and in which there is less stress accumulation $(69,70,73)$.

In the current study, the microtensile test was conducted at a crosshead speed of $1 \mathrm{~mm} / \mathrm{min}$. The applied speed was consistent with ISO [International Organization for Standardization] defined values, and many studies in the literature have used the same speeds [1, 38, 63, 72-77]

As in recent studies evaluating the microtensile bonding strength of resin cement to dentin, in this study, the samples were kept in distilled water at $37^{\circ} \mathrm{C}$ for 48 hours after resin cement polymerization, and then a microtensile test was applied.[63, 73, 78, 79] .

The application of vibration forces is an alternative method to be able to achieve effective cementation of the restoration in the cavity. $(30,74,75)$. Koyano et al. used a vertical oscillation frequency of $35 \mathrm{~Hz}$ and a horizontal oscillation frequency of $50 \mathrm{~Hz}$ to be able to obtain the optimal film thickness for the application of vibration forces (74).

In previous studies, it has been reported that ultrasonic vibrations started the glass ionomer cement setting reaction by increasing the temperature of the environment and that the cement was more uniform in the completed reaction, and porosity was reduced $(12,76,77)$.

The reduction of cement viscosity by the ultrasonic agitation during the cementation procedure and that a thinner and more homogenous film thickness is obtained with reduced porosity with the use of the ultrasonic placement technique $(11,12)$.

In a study by Bagis et al., which evaluated the effect of high ultrasonic frequency on microtensile bond strength of different self-etch adhesives, it was reported that ultrasonic agitation could increase the bond efficacy of adhesives (78).

In a study by Ozcan et al., finger pressure or the ultrasonic placement technique was reported not to have affected the fracture resistance of the indirect restoration (79). In the current study, no statistically significant difference in finger pressure or ultrasonic agitation technique in all the cement groups [p $>0.05]$.

In parallel with the current study, in a study by Bagis et al., which investigated the effect of ultrasonic agitation on bond strength of self-etch adhesives, it was reported that the ultrasonic agitation had not significantly increased the bond strength of adhesives (17).

In the current study, the frequency of the ultrasonic device was $28-32 \mathrm{kHz}$. In the study where Bagis et al. [2009] reported that ultrasonic agitation could increase bond strength of adhesive systems, the frequency of the ultrasonic device used was $1 \mathrm{MHz}$ (78). In another study by Bagis et al. [2008], where it was reported that ultrasonic agitation did not change the bond strength values, the frequency of the ultrasonic device used was the same as that of the current study (17). It can be concluded that the frequency range of the ultrasonic device used in the current study was not high enough to increase the bond strength.

In the comparisons between all the cement groups cemented with the finger pressure, self-adhesive resin cement showed lower $\mu$ TBSs than Panavia F 2.0 and RelyX ARC. There were significant differences between cement; G-Cem showed the lowest and Panavia F 2.0 the highest 
$\mu$ TBSs $[p<0,05]$. But there were no significant differences between G-Cem and RelyX U200 $\mu$ TBSs.

In the comparisons between all the cement groups cemented with the ultrasonic agitation technique, the bond strength values of the Panavia F 2.0 and RelyX ARC groups were found to be statistically significantly higher than G-Cem and RelyX U200 [p $<0.05]$. No statistically significant difference was found between the bond strength values of Panavia F2.0 and RelyX ARC resin cement or between the bond strength values of G-Cem and RelyX U200.

In an in vitro study by Garcia et al., the $\mu$ TBS values were compared of RelyX ARC and three different self-adhesive resins to dentine. The bond strength values of RelyX ARC resin cement were found to be significantly higher than those of all three self-adhesive resin cement (80). According to the previous in-vitro studies, significantly lower $\mu \mathrm{TBSs}$ of RelyX Unicem to dentin compared to Panavia F 2.0 (57, 81), Multilink (81), and Variolink II (82) were reported.

In parallel with the current study, Abo et al. reported that the $\mu$ TBS of all three different self-adhesive resin cement were statistically significantly lower than those of Panavia F 2.0 (64). Tonial et al. reported that the $\mu$ TBS values of RelyX ARC resin cement were significantly higher than those of RelyX Unicem and Maxcem Elite self-adhesive resin cement (83).

In a study by Viotti et al., the $\mu$ TBS to dentine was examined of RelyX Unicem, Maxcem, and G-Cem selfadhesive resin cement and various conventional resin cement. No statistically significant difference was found between the self-adhesive resin cement, and these all demonstrated statistically significantly lower bond strength than some of the conventional resin cement (84). The low bond strength was thought to be due to the superficial bonding to the tooth surfaces of the self-adhesive resin cement compared to the other resin cement (85). RelyX U200 self-adhesive resin cement does not have the capacity to dissolve and demineralize dentine in the same way as RelyX Unicem, so there is, therefore, no decalcification and infiltration on the dentine surface, and a hybrid layer and resin tags can not form $(57,85)$.

According to previous studies, self-adhesive resin cement has lower bond efficiency than resin cement used together with adhesive systems $(10,86-88)$, and when extra retention is not demanded, it has been emphasized that they can be used when conditions are ideal for retention $(10,86)$.
Following the $\mu$ TBS test in the current study, when the failure types were evaluated as a whole, the most common type of failure was seen to be adhesive followed by mixedtype then cohesive. In a study of 5 different adhesive systems, Hubbezoglu et al. determined $81 \%$ adhesive, $19 \%$ mixed, and no cohesive failures (89).

\section{Conclusion}

Resin cement containing MDP used together with adhesive systems should be the first choice in the cementation of ceramic inlay restorations because they had the highest bond strength values. In the cementation of ceramic restorations, if the cases are exposed to a high level of chewing force or have insufficient retention, the use of self-adhesive resin cement should be avoided. According to this study, it can be said that using an ultrasonic device does not increase the adhesion strength of resin cement. However, there are very few studies on this subject in the literature. Therefore, the results obtained in this in vitro study need to be confirmed by a greater number of in-vitro and clinical studies.

\section{References}

1. Akören AC, Üçtaşlı S. Farklı Porselen İnley Sistemleri ve Farklı Yapıştırma Simanlarının Mikrosızıntı Üzerine Etkileri. Türkiye Klinikleri Diş Hekimliği Bilimleri 1998;4:100-105.

2. Küçükeşmen HC. Porselen İnley-Onleyler. Türkiye Klinikleri J Dental Sci-Special Topics 2011;2(1):22-28.

3. Öztürk AN, İnan Ö, İnan E, Öztürk B. Microtensile Bond Strength of Cad-Cam and Pressed-Ceramic Inlays to Dentin. European Journal of Dentistry 2007;2:91-96.

4. Özyeşil AG, Kesim B. Estetik İnleylerin Marjinal Adaptasyonunun İncelenmesi. Cumhuriyet Üniversitesi Dişhekimliği Fakültesi Dergisi 2001;4(2):110-114.

5. Thordrup M, Isidor F, Hörsted-Bindslev P. Comparison of marginal fit and microleakage of ceramic and composite inlays: an in vitro study. Journal of Dentistry 1994;22(3):147153.

6. Rosenstiel SF, Land MF, Fujimoto J. Contemporary Fixed Prosthodontics. Third Edition. St. Louis,Missouri:Mosby, Inc.,Elsevier;2001.

7. CeylanÖ,AykentF. Farklıkorseramiklerin 1şıkgeçirgenliğinin incelenmesi. SÜ Dişhek Fak Derg 2009;18:247-254

8. Uludamar A, Akalın B, Kulak Özkan Y. Zirkonyum esaslı tam seramik restorasyonlarda simantasyon öncesi yüzey hazırlıklar1. Cumhuriyet Dent J 2011;14(2):140-153.

9. Sensat ML, Brackett WW, Meinberg TA, Beatty MW. Clinical evaluation of two adhesive composite cements for the suppression of dentinal cold sensitivity. J Prosthet Dent 2002;88:50-53. 
10. Gerth HU, Dammaschke T, Zuchner H, Schafer E. Chemical analysis and bonding reaction of RelyX Unicem and Bifix composites-a comparative study. Dent Mater 2006;22:934941.

11. Judge RB, Wilson PR. The effects of oscillating forces upon the flow of dental cements. J Oral Rehabil 1999;26:892-899.

12. Towler MR, Crowley CM, Hill RG. Investigation into the ultrasonic setting of glass ionomer cement: Part I Postulated modalities. J Mater Sci Lett 2003;22:539-541.

13. Cantoro A, Goracci C, Coniglio I, Magni E, Polimeni A, Ferrari M. Influence of ultrasound application on inlays luting with self-adhesive resin cements. Clin Oral Invest 2011;15:617-623.

14. Özyöney G. Aşırı madde kayıplı dişlerde IPS Empress II onley restorasyonların klinik ve in vitro şartlarda incelenmesi. Marmara Üniversitesi Sağlık Bilimleri Enstitüsü Diş Hastalıkları ve Tedavisi AD, Doktora Tezi, İstanbul, 2008.

15. Laird WR, Walmsley AD. Ultrasound in dentistry. Part 1Biophysical interactions. J Dent 1991;19:4-7(Abstract).

16. Lea SC, Landini G, Walmsley AD. Vibration characteristics of ultrasonic scalers assessed with scanning laser vibrometry Journal of Dentistry 2002;30:147-151.

17. Bagis B, Turkaslan S, Tezvergil-Mutluay A et al. Effect of ultrasonic agitation on bond strength of self-etching adhesives to dentin. J Adhes Dent 2008;10:441-445.

18. Lea SC, Landini G, Walmsley AD. The effect of wear on ultrasonic scaler tip displacement amplitude. J Clin Periodontol. 2006;33:37-41.

19. Pereira AHA, Tirapelli C, Rodolpho LA. Ultrasonic Dental Scaler Performance Assessment with an Innovative Cavitometer. American Journal of Applied Sciences 2010;7(3):290-300.

20. Buoncristiani J, Seto BG, Caputo AA. Evaluation of ultrasonic and sonic instruments for intraradicular post removal. J Endod 1994;20:486-489.(Abstract).

21. Goon WW. Efficient amalgam core elimination and root preservation with ultrasonic instrumentation. J Prosthet Dent 1992;68:261-264.

22. Lea SC, Landini G, Walmsley AD. Vibration characteristics of ultrasonic scalers assessed with scanning laser vibrometry Journal of Dentistry 2002;30:147-151.

23. Maden M, Orhan EO, Ertuğrul İF. Ultrasonik uç ve ekstraktör kullanılarak kırık kök kanal aletinin çıkartılması: Olgu sunumu. SÜ Dişhek Fak Derg, 2011;20:183-187.

24. Filho ABM, Mori M, Jardini MAN, Landim KT, Solis ACO. Effect of ultrasonic instrumentation on the bond strength of crowns cemented with zinc phosphate cement to natural teeth. An in vitro study. Braz Oral Res 2008;22(3):270-4.

25. Bagis B, Turkaslan S, Tezvergil-Mutluay A et al. Effect of ultrasonic agitation on bond strength of self-etching adhesives to dentin. J Adhes Dent 2008;10:441-445.

26. Roulet JF. Benefits and disadvantages of tooth-coloured alternatives to amalgam. J, Dent. 1997; 25(6): 459-473.

27. Peutzfeldt A. Effect of the ultrasonic insertion technique on the seating of composite inlays. Acta Odontol Scand. 1994;52(1):51-4 (Abstract).
28. Schmidlin PR, Zehnder M, Schlup-Mityko C, Göhring TN. Interface evaluation after manual and ultrasonic insertion of standardized class I inlays using composite resin materials of different viscosity. Acta Odontologica Scandinavica 2005;63(4):205-212.

29. Sjögren G, Hedlund SO. Filler content and gap width after luting of ceramic inlays, using the ultrasonic insertion technique and composite resin cements. Acta Odontol Scand 1997;55(6):403-407.

30. Holand W, Schweiger M, Frank M, Rheinberger V. A Comparison of the Microstructure and Properties of the IPS EmpressT2 and the IPS EmpressT Glass-Ceramics. J Biomed Mater Res (Appl Biomater) 2000;53:297-303.

31. Rathke A, Hokenmaier G, Muche R, Haller B. Effectiveness of the bond established between ceramic inlays and dentin using different luting protocols. J adhes Dent 2012;14:147154 .

32. D'Arcangelo C, De Angelis F, D'Amario M et al. The influence of luting systems on the microtensile bond strength of dentin to indirect resin-based composite and ceramic restorations. Operative Dentistry, 2009;34(3):328-336.

33. De Angelis F, Minnoni A, Vitalone LM et al. Bond strength evaluation of three self-adhesive luting systems used for cementing composite and porcelain. Operative Dentistry 2011;36(6):626-634.

34. Baracco B, Fuentes MV, Garrido MA, Gonzalez-Lopez S, Ceballos L. Effect of thermal aging on the tensile bond strength at reduced areas of seven current adhesives. Odontology 2012. [Epub ahead of print]

35. Goracci C, Cury AH, Cantoro A et al. Microtensile bond strength and interfacial properties of self-etching and selfadhesive resin cements used to lute composite onlays under different seating forces. J Adhes Dent 2006; 8: 327-335(Abstract).

36. Schmidlin PR, Zehnder M, Schlup-Mityko C, Göhring TN. Interface evaluation after manual and ultrasonic insertion of standardized class I inlays using composite resin materials of different viscosity. Acta Odontologica Scandinavica 2005;63(4):205-212.

37. Sjögren G, Hedlund SO. Filler content and gap width after luting of ceramic inlays, using the ultrasonic insertion technique and composite resin cements. Acta Odontol Scand 1997;55(6):403-407.

38. Schulte AG, Vöckler A, Reinhardt R Longevity of ceramic inlays and onlays luted with a solely light-curing composite resin. Journal of Dentistry 2005;33(5):433-442.

39. Fradeani M, Aquilano A, Bassein L. Longitudinal study of pressed glass-ceramic inlays for four and a half years. J Prosthet Dent 1997;78:346-353.

40. Frankenberger R, Lohbauer U, Schaible RB, Nikolaenko SA, Naumann M. Luting of ceramic inlays in vitro: Marginal quality of self-etch and etch-and-rinse adhesives versus selfetch cements. Dental Materials 2008;24:185-191.

41. Fuzzi M, Rappelli G. Survival rate of ceramic inlays. Journal of Dentistry 1998;26:623-626. 
42. Kramer N, Ebert J, Petschelt A, Frankenberger R. Ceramic inlays bonded with two adhesives after 4 years. Dent Mater 2006;22(1):13-21.

43. Kramer N, Frankenberger R. Clinical performance of bonded leucite-reinforced glass ceramic inlays and onlays after eight years. Dent Mater 2005;21(3):262-271.

44. Coelho Santos MJ, Mondelli RF, Lauris JR, Navarro MF. Clinical evaluation of ceramic inlays and onlays fabricated with two systems: two-year clinical follow up. Oper Dent 2004;29(2):123-130 (Abstract).

45. Schulte AG, Vöckler A, Reinhardt R Longevity of ceramic inlays and onlays luted with a solely light-curing composite resin. Journal of Dentistry 2005;33(5):433-442.

46. Tagtekin DA, Özyöney G, Yanikoglu F. Two-year Clinical Evaluation of IPS Empress II Ceramic Onlays/Inlays. Operative Dentistry, 2009;34(4):369-378.

47. Chang JC, Nguyen T, Duong JH, Ladd GD. Tensile bond strengths of dual-cured cements between a glass-ceramic and enamel. J Prosthet Dent 1998;79:503-507.

48. Uludamar A, Aygün Ş, Kulak Özkan Y. Tam seramik restorasyonların simantasyonu. Atatürk Üniv. Diş Hek. Fak. Derg. 2011;21(2):150-162.

49. Bott B, Hannig M. Effect of different luting materials on the marginal adaptation of class I ceramic inlay restorations in vitro. Dental Materials 2003;19:264-269.

50. Öztürk AN, Aykent F. Dentin bonding ajanlar ve simantasyon. Cumhuriyet Üniversitesi Dişhekimliği Fakültesi Dergisi 2001;4(2):128-131.

51. Ozturk N, Aykent F. Dentin bond strengths of two ceramic inlay systems after cementation with three different techniques and one bonding system. J Prosthet Dent 2003;89:275-281.

52. Bitter K, Paris S, Hartwig C, Neumann K, Kielbassa AM. Shear bond strengths of different substrates bonded to lithium disilicate ceramics. Dental Materials Journal 2006;25(3):493502.

53. Borges GA, Sophr AM, De Goes MF, SabrinhaBLC, Chan DCN. Effect of etching and airbone particle abrasion on the microstructure of different dental ceramics, J. Prosthet. Dent. 2003;89:479-488.

54. Nagai T, Kawamoto $Y$, Kakehashi $Y$, Matsumura $H$. Adhesive bonding of a lithium disilicate ceramic material with resin-based luting agents. Journal of Oral Rehabilitation 2005;32:598-605.

55. Pisani-Proenca J, Erhardt MCG, Valandro LF et al. Influence of ceramic surface conditioning and resin cements on microtensile bond strength to a glass ceramic. J Prosthet Dent 2006;96:412-417.

56. Spohr AM, Sobrinho LC, Consani S, Sinhoreti MAC, Knowles JC. Influence of surface conditions and silane agent on the bond of resin to IPS Empress 2 ceramic. Int $\mathrm{J}$ Prosthodont 2003;16:277-282.

57. Filho AM, Vieira LCC, Araujo E, Junior SM. Effect of Different Ceramic Surface Treatments on Resin Microtensile Bond Strength. J Prosthodont 2004;13(1):28-35.

58. Yang B, Ludwig K, Adelung R, Kern M. Micro-tensile bond strenght of three luting resins to human regional dentin. Dent Mat 2006;22:45-56.
59. Öztürk AN, Aykent F. İki farklı seramik inley sisteminin bağlanma dayanımına kalan dentin kalınlığının etkisinin araştırılması. Cumhuriyet Üniversitesi Dişhekimliği Fakültesi Dergisi 2001;4(2):75-79.

60. De Munck J, Van Landuyt K, Peumans M et al. A critical review of the durability of adhesion to tooth tissue: methods and results. J Dent Res 2005;84(2):118-132.

61. Knobloch LA, Gailey D, Azer S et al. Bond strengths of one- and two-step self-etch adhesive systems. J Prosthet Dent 2007;97:216-22.

62. Peumans M, Kanumilli P, De Munck J et al. Clinical effectiveness of contemporary adhesives: A systematic review of current clinical trials. Dental Materials 2005;21(9):864881.

63. Villela-Rosa ACM, Gonçalves M, Orsi IA, Miani PK. Shear bond strength of self-etch and total-etch bonding systems at different dentin depths. Braz Oral Res. 2011;25(2):109-115.

64. Abo T, Uno S, Yoshiyama M, Yamada T, Hanada N. Microtensile bond strength of self-adhesive luting cements to ceramics. International Journal of Dentistry 2012;1-5.

65. Al-Assaf K, Chakmakchi M, Palaghias G, KaranikaKouma A, Eliades G. Interfacial characteristics of adhesive luting resins and composites with dentine. Dent Mater. 2007;23:829-39.

66. Peutzfeldt A. Effect of the ultrasonic insertion technique on the seating of composite inlays. Acta Odontol Scand. 1994;52(1):51-4 (Abstract).

67. Ferrari M, Breschi L, Grandini S. Fiber Posts and Endodontically Treated Teeth: A Compendium of Scientific and Clinical Perspectives. Modern Dentistry Media , First edition, Johannesburg, South Africa, 2008, p:109.

68. Van Meerbeek B, Peumans M, Poitevin A et al. Relationship between bond-strength tests and clinical outcomes. Dental Materials 2010;26(2):e100-e121.

69. Yoshida Y, Nagakane K, Fukuda R et al. Comparative Study on Adhesive Performance of Functional Monomers. J Dent Res 2004;83(6):454-458.

70. Sano H, Shono T, Sonoda Het al. Relationship between surface area for adhesion and tensile bond strength- Evaluation of a microtensile bond test. Dent Mater 1994;10(4):236-240.

71. Schreiner RF, Chappell RP, Glaros AG, Eick JD. Microtensile testing of dentin adhesives. Dent Mater 1998;14:194-201.

72. Hamouda IM, Samra NR, Badawi MF. Microtensile bond strength of etch and rinse versus self-etch adhesive systems Journal of the Mechanical Behavior of Biomedical Materials 2011;4:461-466.

73. Valandro LF, Della Bona A, Bottino MA and Neisser MP. The effect of ceramic surface treatment on bonding to densely sintered alumina ceramic. J Prosthet Dent 2005;93:253-259.

74. Duymus Yesil Z. Microtensile bond strength testing of resin cements. International Journal of Adhesion \& Adhesives 2009;29:352-355.

75. Koyano E, Iwaku M, Fusayama T. Pressuring techniques and cement thickness for cast restorations. Journal of Prosthetic Dentistry, 1978;40:544 (Abstract) .

76. Noack MJ, Locke LS, Roulet JF. Das Randverhalten adhbiv befestigter und mittels Ultraschall eingesetzter 
Porzellan inlays in vivo. Deutsche Zahniirztlithe Zeitschr@, 1993;48:115-118 (Abstract).

77. Towler MR, Crowley CM, Hill RG. Investigation into the ultrasonic setting of glass ionomer cement: Part I Postulated modalities. J Mater Sci Lett 2003;22:539-541.

78. Twomey E, Towler MR, Crowley CM, Doyle J, Hampshire $\mathrm{S}$. Investigation into the ultrasonic setting of glass ionomer cements. Part II: setting times and compressive strengths. J Mater Sci 2004;39:4631-4632.

79. Towler MR, Bushby AJ, Billington RW, Hill RG. A preliminary comparison of the mechanical properties of chemically cured and ultrasonically cured glass ionomer cements, using nano-indentation techniques. Biomaterials 2001; 22:1401-1406.

80. Bagis B, Turkaslan S, Vallittu PK, Lassila LV. Effect of high frequency ultrasonic agitation on the bond strength of selfetching adhesives. J Adhes Dent. 2009;11(5):369-74.

81. Özcan M, Mese A. Effect of Ultrasonic Versus Manual Cementation on the Fracture Strength of Resin Composite Laminates. Operative Dentistry 2009;34(4):437-442.

82. Bagis B, Turkaslan S, Tezvergil-Mutluay A et al. Effect of ultrasonic agitation on bond strength of self-etching adhesives to dentin. J Adhes Dent 2008;10:441-445.
83. Escribano N, de la Macorra JC. Microtensile bond strength of self-adhesive luting cements to ceramic. J Adhes Dent 2006; 8: 337-341(Abstract).

84. Yang B, Ludwig K, Adelung R, Kern M. Micro-tensile bond strenght of three luting resins to human regional dentin. Dent Mat 2006;22:45-56.

85. Piwowarczyk A, Bender R, Ottl P, Lauer HC. Long-term bond between dualpolymerizing cementing agents and human hard dental tissue. Dent Mater 2007; 23: 211-217.

86. Tonial D, Ghiggi PC, Lise AA et al. Effect of conditioner on microtensile bond strength of self-adhesive resin cements to dentin. Baltic Dental and Maxillofacial Journal 2010;12:7379.

87. Viotti RG, Kasaz A, Pena CE et al. Microtensile bond strength of new self adhesive luting agents and conventional multistep systems. J Prosthet Dent 2009;102:306-312.

88. De Munck J, Vargas M, Van Landuyt $\mathrm{K}$ et al. Bonding of a self-adhesive luting material to enamel and dentin. Dent Mater 2004;20:963-971.

89. Yesilyurt C, Bulucu B. Bond Strength of Total-Etch Dentin Adhesive Systems on Peripheral and Central Dentinal Tissue: A Microtensile Bond Strength Test. J Contemp Dent Pract 2006;7(2):26-36. 